FOCUS: Journal of International Business Volume 4, Issue 1, January-June 2017, pp. 115-136 doi: 10.17492/focus.v4i01.9535

\title{
India's Look East Policy: Relationship with ASEAN and Opportunities for North East India
}

\author{
Shankar Jyoti Doley*
}

\begin{abstract}
The intensification of the process of globalisation, liberalisation and privatisation has led to fundamental changes in the global political and economic architecture. In this changing political and economic context, India needed to take timely initiatives to integrate its economy with the global economy, which led to the adoption of New Economic Policy. The New Economic Policy of 24th July, 1991 is known as the precursor to the Look East Policy (LEP) of India. The 'Look East policy' has been a major part of India's international engagement since its economic opening in 1991. The Look East Policy was initiated with the objective of liberalisation of India's economy and improving its economic situation in North East India region. This paper analyses the impact of the India's Look East Policy on the growth and development of North East region of India. In general, the potential benefits of the Look East policy are not being fully utilised because of inadequate infrastructure and political ignorance.
\end{abstract}

Keywords: Look East policy; Free Trade Agreement; ASEAN; Foreign direct investment; North-East.

\subsection{Introduction}

The evolution of India's Look East policy can be traced back to the changing world economic environment in the early 1990s. India opened up its economy in 1991 with the introduction of New Economic policy. Around this period of time, the internal economic and political situation of India was worsening. The 1990 Gulf crisis had a deep impact on India's economy as it depended much on the West Asian countries for oil and trade. The collapse of the Soviet Union created a strategic and economic vacuum for India, since USSR was a major trading partner of India.

*Assistant Professor, Department of Commerce, Delhi School of Economics, University of Delhi, Delhi, India. (Email id: sjshan29@gmail.com) 
Also trade with the Eastern European countries had suffered severely with the end of communist rule. All these socio-economic factors deeply affected India's economy, bringing about economic recession and an acute balance-of-payments crisis by mid-1991. India's foreign exchange reserves had fallen to barely enough to cover two weeks imports and India was forced to seek the help of the International Monetary Fund (IMF). The situation was worsened by the unstable political scenario of India during this period in which three successive governments were formed within two years. Fundamentals of global economies are led by intensification of the process of liberalisation, privatisation and globalisation. In this changing political and economic context, India needed to adjust herself with the evolving international situation. Integration with the global economy was an urgent necessity for India, hence adoption of New Economic Policies. The New Economic Policy of 24th July, 1991 is known as the precursor to the Look East Policy (LEP) of India which was initiated by the then Prime Minister Narasimha Rao and Finance Minister Dr. Manmohan Singh. The dynamism of India's Eastern neighbours made Southeast Asia an attractive place to start the regional economic integration process. As per as energy sources are concern the south-east Asian nations were apt replacement for gulf countries. The Look-East policy was officially launched in 1991.India was driven by desire to develop and stabilise its fragile NorthEastern states, which were under constant threat of terrorism and insurgency resulting severe underdevelopment in the whole region. As all the North-Eastern states share international boundary, they are very critical to overland connectivity with South-East Asia. The objective of this now called "Act East Policy" is to promote regional economic cooperation, sustained economic growth, cultural ties and develop strategic relationship with countries in the Asia-Pacific region through continuous engagement at bilateral, regional and multilateral levels thereby providing enhanced connectivity to the States of North Eastern Region to ensure development and growth of the region. The North East of India has been a priority in Act East Policy (AEP).

\subsection{Second Phase of India's Look East Policy}

The first phase of the India's Look East policy was primarily centered on the ASEAN. During this phase India was trying to enhance the trade and investment ties with ASEAN nations. In 1998, the then Prime Minister of India, Mr. Atal Bihari Vajpayee pushed for more reforms to accelerate the economic and political ties beyond ASEAN nations. The extended neighbourhood includes Japan, Korea, Australia, and New Zealand. The year 2003 was the time when the Look East Policy entered its second phase with the initiation of term 'extended neighbourhood'. This extended neighbourhood was endorsed by few political leaders specifically I.K. Gujral and then 
Foreign Minister Jaswant Sinha. In 2003, Mr. Jaswant Sinha emphasised on the need of wider economic and political ties with the 'extended neighborhood'. Mr. Sinha stated that, the first phase of India's Look East Policy was ASEAN-centered and focused primarily on trade and investment linkages. The new phase of this policy is characterized by an expanded definition of 'East' extending from Australia to East Asia, with ASEAN at its aim. The new phase also marks a shift from trade to wider economic and security issues including joint efforts to protect the sea lanes and coordinate counter-terrorism activities. On the economic side, phase second is also characterised by arrangement for FTA and establishing institutional economic linkage between the countries of the region and India.

The second phase of Look East Policy of India has significant amount of impact on the relation with East Asian nations and Australian continent, in terms both trade and investment and political and security ties. As a goodwill gesture, India-ASEAN signed Free Trade Agreement in goods, services and investment in 2010. This has eased the cross border movement of goods, capital, labour and services which would lead to welfare of the consumers of both region. The governments of Japan and India started negotiating a comprehensive Economic Partnership Agreement in January 2007. Finally the two of Asia's largest economies, signed a landmark free trade agreement (FTA) in 2011. This has paved the way for the elimination of tariffs on more than 90 percent of goods traded between the two countries. Bilateral trade between the two countries was worth $\$ 10.3$ billion in 2009-10, which has increased to US\$ 14.51 billion in the financial year 2015-16. Bilateral trade between India and Japan is expected to reach US\$50 billion by 2050 (Ministry of Foreign Affairs of Japan). As consequences of the signing of Free Trade Agreement, as many as 9,000 products ranging from steel and apparel to drugs and machinery could be traded either without duty or at substantially reduced tariffs. Japan is the fourth largest foreign investor in India. The amount of Japan's cumulative investment in India since April 2000 to September 2016 is US\$ 23.76 billion, (Ministry of Foreign Affairs of Japan) which is nearly 8 per cent of India's overall FDI during this period. India sees the Republic of Korea as an indispensable partner in its "Act East" strategy. South Korea is one of the earliest foreign investors in India after economic liberalization in 1991. South Korean companies including Samsung, LG and Hyundai are among the most respected companies in India. The Comprehensive Economic Partnership Agreement (CEPA) between the two countries was implemented in January 2010. In 2016 June, India and South Korea reviewed their free trade agreement (FTA) with a view to further strengthen bilateral economic ties. The bilateral trade between India and South Korean stood at US\$ 16.59 billion in 2015-16 (Institute of Defence Studies and Analysis). The bilateral trade and investment relationship between 
India and Australia has been progressed rapidly. As of financial year 2014-15, India was Australia's tenth largest trading partner accounting for almost 18 billion Australian dollar (MEA of India). Signing of the India-Australia Free trade agreement (FTA) or Comprehensive Economic Cooperation Agreement (CECA) is in advanced stage and is likely to be inked soon.

\subsection{Objective and rationale}

The objective of this paper is to study possibilities of greater trade and business relation between India-ASEAN as an impact of the Look East Policy. We will try to analyse the growing ties in respect of areas such as trade in goods and services, investments and flow of capital etc. Further, one of the objectives of this paper is to identify the opportunities for North-East region of India if the Look East Policy is implemented proactively.

The rationale behind this paper is the growing importance of India-ASEAN relationship. Both regions have been experiencing high growth rate. Further, IndiaASEAN are bestowed with huge consumer base and untapped natural resources. These regions have the potential to lead the global economic growth in near future. North-East of India can be gateway to ASEAN market because of its geographical proximity.

\subsection{Review of Literature}

This section reviews the existing literature on India-ASEAN relations and the Look East policy. Haokip (2011) observes that India's Look East policy has emerged as an important foreign policy initiative of India in the post-Cold War period. The political and economic developments in different parts of the world during the early 1990s brought radical changes in the relations among nations, resulting in the emergence of an era of globalisation. Globalisation brought about an increasing integration of economies and societies and threw open opportunities and challenges to both the developed and developing countries. The collapse of the Soviet Union was therefore a big loss for India in political, strategic and economic terms. The Asia-Pacific region was the best alternative available to India post the Gulf crisis; so India was forced to Look East. Morarji and Sharma (2015) observe that though diplomatic and economic efforts were made by India to join ASEAN since 1987, these countries expressed reservations due to India's support to the Heng Samrin regime. Moreover, they were apprehensive that Pakistan would also seek membership of ASEAN in which case, ASEAN would become a platform for a spat between India and Pakistan. According to Sundaram (2013), the Look East policy is an attempt to forge closer and deeper economic integration with its 
eastern neighbours as a part of the new realpolitik in evidence in India's foreign policy and the engagement with Association of South East Asian Nations (ASEAN) is the recognition on the part of India's elite of the strategic and economic importance of the region to the country's national interests. As Prime Minister Manmohan Singh once said, the Look East policy is "not merely an external economic policy; it is also a strategic shift in India's vision of the world and India's place in the evolving global economy." Saikia (2010) believes that during the process of closer economic integration, India faced the hurdles of lack of significant market for most South-East Asian economies, insurgency problem, delayed infrastructural development, inefficient bureaucracy, and complex socio-cultural and ethnic frameworks. India-ASEAN economic relations improved over the years, leading to multifaceted institutional arrangements being developed by the two sides. Chatterjee (2007) finds that positive engagement with Southeast Asia in the post-Cold War era began in the 1990s when India became a Full Dialogue Partner (in 1995) and a member of the ASEAN Regional Forum (in 1996). Since then, India has regularly though not always effectively participated in the deliberations of the forum in both the capacities. Despite some initial setbacks during the Asian financial crisis and the Pokhran nuclear tests, positive factors such as the pursuit of a simultaneous 'Look West' policy by ASEAN have registered impressive progress in strengthening comprehensive Indo-ASEAN relations in the initial stages of cooperation.

The twenty-first century has seen more comprehensive engagement between India and ASEAN. There are three main issues facing India in the Southeast Asian region (Haokip, 2015). First, stabilising the North-East, its clandestine flows and foreign connections; second taking advantage of the proximity of Southeast Asian nations, especially Myanmar, to step onto the Asian diplomatic and economic scene; and finally, measuring the impact of China's influence on the Myanmar regime and its consequences for the country's interests. The emergence of the Asian Tigers and the growth of ASEAN as leading economies of Asia provided further impetus for the Indian policymakers to look at the East as a possible avenue for conducting economic transaction. Jyoti (2013) discusses the second phase of India's Look East Policy and finds that India was looking to develop association with countries beyond its immediate neighbourhood, perceiving countries in the East and North-East Asia as its far eastern neighbours and the ASEAN countries as its near eastern neighbours. Phase two broadened the scope of Look East policy. It included new and expanded areas of cooperation such as trans-regional infrastructure, transportation, communication, HRD, Science and Technology including the knowledge areas, agriculture, trade and investment, energy, environment, culture and people-to-people contacts. Gogoi (2014) discusses the emerging trends of regional cooperation identified as a strategic way to harness the comparative advantage of North 
East Region. This led to path the new way for the development of NER with more and more liberalize the geo-political rigidities, NER is expected to be the beneficiary of the "Look East Policy" due to its geographical advantage vis à vis-the Southeast Asian Countries. NE region is the gate way to the ASEAN region. This region is not in a position to earn the benefit of international trade from the west. So looking to east is obviously a natural opportunity for the upliftment of international trade and economic growth of this region. North East Indians think of South East Asian countries as their neighbours. But in a maritime sense, the east cost of India - Orissa, Andhra or Tamil Nadu - is also next door to South East Asia (Singh and Singh, 2014). Indeed, historically mainland India's ties with South East Asia have been more maritime than continental. It may be tempting therefore for India to build relationships with South East Asia that are primarily maritime rather than continentally oriented. Barua and Das (2008) observe that the crux of the problem of development of NER is not the lack of integration with the booming East and the Southeast Asian markets. The crucial problems of development faced by the region are the lack of intra-regional as well as intra-state connectivity, infrastructure and the issues of security and governance.

\subsection{A Brief Overview of ASEAN}

ASEAN (Association of Southeast Asian Nations) consists of ten nations namely Brunei Darussalam, Cambodia, Indonesia, Laos, Malaysia, Myanmar, Philippines, Singapore, Thailand, and Vietnam. (1 Observer - Papua New Guinea). ASEAN was formed in August, 1967 by Indonesia, Malaysia, Philippines, Singapore, and Thailand. Its principal aims include accelerating economic growth, social progress, and sociocultural evolution among its members, alongside the protection of regional stability and the provision of a mechanism for member countries to resolve disputes peacefully. The size of ASEAN economy stands at US\$2.8 trillion in 2015. ASEAN as a single entity is the third largest economy in Asia and sixth largest in the world. ASEAN shares land borders with India, China, Bangladesh, East Timor, and Papua New Guinea, and maritime borders with India, China, and Australia.

\subsection{ASEAN-India relations}

ASEAN-India relations have taken positively strong direction only in 1990s, when India was opening up economy to march towards economic liberalisation, even though India was provided with the opportunity of being a founding member of ASEAN. The ASEAN-India Free Area emerged from a mutual interest of both parties to expand 
their economic ties in the Asia-Pacific region. India's search for economic space in the Asia-Pacific region resulted in the 'Look East Policy'.

Since the initiation of the Look East policy in 1991, bilateral relations between India and ASEAN have progressed rapidly. India became a sectoral dialogue partner of ASEAN in 1992 in three areas namely trade, investment and tourism (Table 1). With the sectoral dialogue partnership, India saw its trade with ASEAN increased rapidly relative to its trade with the rest of the world. Between 1993 and 2003, ASEAN-India bilateral trade grew at an annual rate of $11.2 \%$, from US $\$ 2.9$ billion in 1993 to US $\$ 12.1$ billion in 2003. Much of India's trade with ASEAN is directed towards Singapore, Malaysia, and Thailand, with whom India holds strong economic relations. India-ASEAN relations were upgraded to a Full Dialogue Partnership at the fifth ASEAN Summit in Bangkok in December 1995 (Table 1).

Table 1: India-ASEAN Relations Timeline

\begin{tabular}{|l|l|}
\hline 1992 & A sectoral dialogue partner with ASEAN \\
\hline 1995 & A full dialogue partner \\
\hline 1996 & A member of ASEAN regional forum \\
\hline 2002 & First India-ASEAN summit \\
\hline 2004 & India and Thailand signed FTA \\
\hline 2009 & India-ASEAN singed FTA \\
\hline
\end{tabular}

The cooperation between India-ASEAN has also got the required push with the initiation of Look East Policy and with positive acknowledgement from ASEAN nations. The increasingly close cooperation between India and ASEAN led to the strengthening of not only economic ties but also security linkages, resulting in India's admission to the ASEAN Regional Forum (ARF) in 1996. India-ASEAN relations were upgraded to a Summit Level Partnership in 2002. India became one of the four ASEAN Summit Level Partners along with Japan, China and Korea. For comprehensive economic cooperation and trade relation, India finally signed the ASEAN-India Free Trade Agreement (FTA) with the 10 members of ASEAN in August 2009. After signing the FTA in 2009, trade and economic relations between India and ASEAN have increased to US\$ 48 billion. The ASEAN-India FTA expected to see tariff liberalisation of over 90 percent of products traded between the two regions. Over the next decade tariffs on over 4000 products are expected to eliminate. Total trade between India and ASEAN stands at US\$65 billion in 2015-16 (MEA of India). In 2003, the scope of India's Look East 
policy was expanded to include the East Asian nations such as China, Japan and Korea. Bilateral trade and investment between India and all these countries have significantly improved over the last decade. And these economic ties would take only positive direction and new dimensions in next few decades because of the fact that both India and ASEAN are blessed with huge consumer base and bestowed with abundant natural resources. The ASEAN bloc's real GDP is expected to grow at $6 \%$ in the next five years (asean.org). In the same time period India is expecting a growth rate of at least $8 \%$. But from the past experience it was seen that even if India has been growing constantly at decent rate, the North Eastern part of India has not been blessed too much from such growth rate. Rather the development over all in the region has been dismal. One of the main aim of the Look East Policy was to challenge that trend and bring growth parity in the region. India and the Association of Southeast Asian Nations (ASEAN) signed the Free Trade Agreement (FTA) in services and investments on September 8, 2014. The signing of FTA is expected to bring much needed pace to ASEAN - Indian Relations, hence growth and development to whole North East region due to its geographical proximity with the ASEAN countries and due to growing economic stature of the ASEAN countries. Table 2 presents an idea of how the ASEAN economies are growing.

Table 2: Growth Rate of ASEAN Nations (2015) (US \$)

\begin{tabular}{|l|l|l|l|l|l|}
\hline Country & $\begin{array}{l}\text { Population } \\
\mathbf{( , 0 0 0 )}\end{array}$ & $\begin{array}{l}\text { Growth } \\
\text { Rate }(\mathbf{\%})\end{array}$ & $\begin{array}{l}\text { GDP } \\
(\mathbf{m i l l i o n})\end{array}$ & Per capita & $\begin{array}{l}\text { FDI net } \\
\text { inflow } \\
\text { (million) }\end{array}$ \\
\hline Brunei Darussalam & 417 & -0.6 & $12,909.0$ & 30,942 & $(396.9)$ \\
\hline Cambodia & 15,405 & 7.1 & $18,463.0$ & 1,198 & $(25.6)$ \\
\hline Indonesia & 255,462 & 4.8 & $857,603.3$ & 3,357 & $(5,737.6)$ \\
\hline Laos & 6,902 & 7.6 & $12,639.3$ & 1,831 & 165.9 \\
\hline Malaysia & 30,485 & 5 & $294,389.6$ & 9,657 & 414.3 \\
\hline Myanmar & 52,476 & 7.1 & $65,391.8$ & 1,246 & $1,878.3$ \\
\hline Philippines & 101,562 & 5.8 & $289,502.8$ & 2,850 & $(90.4)$ \\
\hline Singapore & 5,535 & 2.0 & $291,937.6$ & 52,744 & $(13,135.5)$ \\
\hline Thailand & 68,979 & 2.8 & $395,726.3$ & 5,737 & $4,307.3$ \\
\hline Vietnam & 91,713 & 6.7 & $193,406.7$ & 2,109 & $2,599.9$ \\
\hline ASEAN & 628,937 & 4.7 & $2,431,969.5$ & 3,867 & $(10,020.2)$ \\
\hline Source: asean.org & & & & &
\end{tabular}

\subsection{FDI inflows into ASEAN}

ASEAN's rapidly growing middle class, large population, huge consumer base and large scale infrastructure and connectivity needs underpin its strong potential as an 
investment destination. Total FDI inflows into the ASEAN region have remained steady. The FDI inflows reached their pick in 2014, reaching US $\$ 136.2$ billion. FDI flows to the ASEAN region declined by 8 per cent, from $\$ 136$ billion in 2014 to $\$ 120$ billion in 2015 . Falls in FDI in services, cross-border mergers and acquisitions and lower intra company loans were the main reasons behind this development. FDI in manufacturing rose, equity capital financing of FDI activities was at an all-time high, and regional investment expansion by MNEs remained strong. Intra-ASEAN investment remained the largest source of FDI flows, rising marginally by $\$ 15$ million to $\$ 22.1$ billion last year. Table 3 provides data on the net FDI inflows into various ASEAN economies. In terms of top sources of FDI inflows into ASEAN, the European Union tops the list (Table 4).

Table 3: FDI Net Inflows, intra-ASEAN and extra-ASEAN

\begin{tabular}{|l|c|c|c|c|}
\hline \multirow{2}{*}{ Country } & \multicolumn{2}{|c|}{ Intra-ASEAN } & \multicolumn{2}{c|}{ Extra-ASEAN } \\
\cline { 2 - 5 } & $\mathbf{2 0 1 4}$ & $\mathbf{2 0 1 5}$ & $\mathbf{2 0 1 4}$ & $\mathbf{2 0 1 5}$ \\
\hline Brunei & 141.2 & 86.7 & 427.0 & 84.7 \\
\hline Cambodia & 372.5 & 425.4 & $1,354.0$ & $1,275.6$ \\
\hline Indonesia & $13,083.7$ & $9,499.0$ & $8,726.7$ & $7,417.8$ \\
\hline Laos & 137.9 & 221.8 & 775.3 & 857.3 \\
\hline Malaysia & $2,284.0$ & $2,719.0$ & $8,591.3$ & $8,570.6$ \\
\hline Myanmar & 683.6 & $2,230.6$ & 262.6 & 593.8 \\
\hline Philippines & 137.1 & 66.2 & $5,677.5$ & $5,658.0$ \\
\hline Singapore & $5,214.1$ & $3,416.3$ & $69,206.2$ & $57,868.5$ \\
\hline Thailand & $(1,466.8)$ & $1,413.7$ & $5,187.0$ & $6,613.8$ \\
\hline Vietnam & $1,547.1$ & $2,153.5$ & $7,653.0$ & $9,646.5$ \\
\hline ASEAN & $19,393.3$ & $17,200.9$ & $97,815.7$ & $86,213.3$ \\
\hline Source: asean & & & &
\end{tabular}

Source: asean.org

The bilateral investments flows between India and ASEAN have been progressive in the last decade. Singapore has emerged as one of the top source of FDI for India with total FDI amount of US\$ 5137 in the year 2014-15 (Table 5). India is emerging as investment destination, particularly for institutional investors in Singapore and ASEAN who are eyeing overseas market for yield and diversification. India has undertaken liberalisation of FDI including raising investment limits, fast government approvals, simplifying investment conditions and opening up new sectors such as defence, insurance and retail etc. to FDI. The launch of "Make in India" campaign in 
September, 2014, is aimed at attracting companies to use India as a global manufacturing hub, is attracting more investments.

Table 4: Top Sources of Foreign Direct Investment Inflows in ASEAN

\begin{tabular}{|l|c|c|c|}
\hline Country & $\mathbf{2 0 1 3}$ & $\mathbf{2 0 1 4}$ & $\mathbf{2 0 1 5}$ \\
\hline European Union (EU) & $24,511.3$ & $24,989.9$ & $20,127.6$ \\
\hline Japan & $24,750.2$ & $15,705.4$ & $17,559.4$ \\
\hline USA & $7,157.2$ & $14,748.5$ & $13,646.0$ \\
\hline China & $6,426.2$ & $6,990.1$ & $8,256.5$ \\
\hline Republic of Korea & $4,303.3$ & $5,750.7$ & $5,710.4$ \\
\hline Australia & $2,587.7$ & $6,281.5$ & $5,246.7$ \\
\hline India & 5294 & 7429 & 4385 \\
\hline Source: asean.org
\end{tabular}

Table 5: FDI Inflows into India from ASEAN and the World

\begin{tabular}{|l|c|c|c|}
\hline \multicolumn{4}{|c|}{ (US\$ million) } \\
\hline Source & $\mathbf{2 0 1 2 - 1 3}$ & $\mathbf{2 0 1 3 - 1 4}$ & $\mathbf{2 0 1 4 - 1 5}$ \\
\hline Total FDI Inflows & 18,286 & 16,054 & 24,748 \\
\hline FDI Inflows ASEAN & 1843 & 4528 & 5356 \\
\hline Singapore & 1605 & 4415 & 5137 \\
\hline
\end{tabular}

Source: $M E A \&$ \&EA, India

\subsection{Investment and trade opportunities between India and ASEAN countries}

ASEAN is very dynamic and rapidly growing region and it is managing its diversity and growth effectively. From 1990 to 2005, ASEAN trade experienced a per annum growth rate of over 10 percent. Currently its economy is expanding at $4.6 \%$ annually Economist and experts has forecasted the growth rate to pick up in 2017. Interestingly, the fuel for trade growth is coming from within the region. The intra ASEAN growth rate has been more than $10 \%$ in last few years. Similar to ASEAN economy, India has also attained a place of prominence at the global stage. India is sixth largest economy of the world with nominal GDP size of US\$2.30 trillion. Currently it has been experiencing a healthy growth rate of $7.6 \%$. So we can say that the two regional markets (i.e. India and ASEAN) can be combined to yield a market of huge potential for growth and investment by both domestic and international investors. Table 6 provides a glimpse of current status and potential of India and ASEAN. The total population combined is bit less than 2 billion which is approximately $26 \%$ of the world population. This is a huge consumer base most of which is comprise of middle class people. Such a 
huge potential consumer base can attract any investors from all over the world. With such market potential Foreign Direct Investment has been already flowing in which can be seen from above data. As on 2015-16, the combined FDI inflows stand at US\$ 529.75 billion (Table 6).

Table 6: India-ASEAN: Current Status and Potential (2015-16)

\begin{tabular}{|l|c|c|c|}
\hline Economic Indicators & India & ASEAN & $\begin{array}{c}\text { Combined } \\
\text { Market Size }\end{array}$ \\
\hline Geographical Area (sq.km) & 3290.0 & 4464.3 & 7754.3 \\
\hline Population (mn) & 1252 & 630 & 1882 \\
\hline Gross Domestic Product (US\$bn) & 2300 & 2570 & 4870 \\
\hline FDI(inflows US\$bn) Exchange Reserves & 282.27 & 247.48 & 529.75 \\
\hline $\begin{array}{l}\text { Foreign } \\
\text { (US\$bn) }\end{array}$ & 367 & 850 & 1217 \\
\hline
\end{tabular}

Source: RBI and asean.org

Apart from the market potential, the investors and economist are also optimistic about the ASEAN and Indian emerging markets because of the strong economic and financial fundamentals. The financial creditability of both the region can be gauge from the huge Foreign Exchange Reserve. The combined Foreign Exchange Reserve is US\$ 1217 billion as on 2015-16. Such huge market potential and strong economic fundamentals in both the regions have resulted in rapid growth in bilateral trade and investment. More over these have been complimented by signing Free Trade and Agreements on Trade in Services and Investments. Investment flows are also substantial both ways, with ASEAN accounting for approximately $12.5 \%$ of investment flows into India since 2000. FDI inflows into India from ASEAN between April 2000 to May 2016 was about US\$49.40 billion, while FDI outflows from India to ASEAN countries, from April 2007 to March 2015, as per data maintained by Department of External Affairs, was about US\$38.672 billion. Table 7 gives a picture of the India-ASEAN merchandise trade and its recent trends. India-ASEAN trade and investment relations have been growing steadily, with ASEAN being India's fourth largest trading partner. The annual trade between India and ASEAN stood at approximately US\$ 76.53 billion in 2014-15. It declined to US\$ 65.04 billion in 2015-16 essentially due to declining commodity prices amidst a general slowing down of the global economy. In 2005-06, Singapore accounted for more than 50 $\%$ share in India's total exports to ASEAN followed by Indonesia, Malaysia with a market share of $13 \%, 11 \%$ respectively. After a decade, in 2015-16, export shares in the 
ASEAN market have undergone a major change with Singapore, Vietnam, Malaysia, Thailand and Indonesia accounting for a share of $31 \%, 21 \%, 15 \%, 12 \%$ and $11 \%$ in India's total exports to the ASEAN. In 2005-06, Singapore was largest source of import for India with 31\% share of ASEAN's total export to India. But in 2015-16, Indonesia has overtaken Singapore as largest import source for India with 34\% of ASEAN. India's net trade deficit with ASEAN in 2015-16 was US\$ 14.6 billion.

Table 7: India-ASEAN Merchandise Trade

\begin{tabular}{|l|c|c|c|c|c|}
\hline Year & $\begin{array}{l}\text { India's export } \\
\text { to ASEAN }\end{array}$ & $\begin{array}{l}\text { Share in } \\
\text { India's Total } \\
\text { export }\end{array}$ & $\begin{array}{l}\text { India's } \\
\text { import from } \\
\text { ASEAN }\end{array}$ & $\begin{array}{l}\text { Share in } \\
\text { India's total } \\
\text { import }\end{array}$ & $\begin{array}{l}\text { Total } \\
\text { trade }\end{array}$ \\
\hline $2010-11$ & 25.63 & 10.3 & 30.61 & 8.3 & 56.24 \\
\hline $2011-12$ & 36.74 & 12 & 42.16 & 8.6 & 78.9 \\
\hline $2012-13$ & 33.00 & 11 & 42.87 & 8.7 & 75.87 \\
\hline $2013-14$ & 33.13 & 10.5 & 41.28 & 9.2 & 74.41 \\
\hline $2014-15$ & 31.81 & 10.2 & 44.71 & 10.0 & 76.52 \\
\hline $2015-16$ & 25.20 & 9.6 & 39.84 & 10.5 & 65.04 \\
\hline
\end{tabular}

Source: The Associated Chambers of Commerce and Industry of India (ASSOCHAM)

Petroleum oils and meat products accounted for a share of about $15 \%$ and $10.5 \%$ of India's total exports to ASEAN respectively. Other top export items to ASEAN were transport equipment (8.5\%), chemicals (6.7\%), mechanical appliances (6.4\%), nonferrous metals $(5.2 \%)$, iron \& steel (2.9\%) and pharmaceuticals $(2.8 \%)$. In contrast, India's imports from ASEAN are dominated by petroleum oils, palm oil, coal briquettes, chemicals, electrical and electronic equipment and mechanical appliances. These five items accounted for more than 50\% share in India's total imports from ASEAN.

\subsection{Impact of Look East Policy on India-ASEAN relations}

Government of India initiated the Look East policy (LEP) in the early 1990s. Later, in 2014, the Government decided to emphasize on the implementation aspect by terming it as "Act East". This decision was probably made in light of the realisation that although many plans and policies have been formulated, their execution has been abysmal. Today is the prime time of globalisation and it is opportunity both "look" and "act" East as India's relations with Myanmar and Bangladesh are already in a good shape and are projected to improve from here on. As of now the Look East Policy's 
contribution to India-ASEAN relation has been to greatly significant. Yet we can sum up the following positive from the Look East Policy of India.

\subsubsection{Economy and trade}

As already discussed, the economy and trade relationship has been constantly growing at a rapid pace. Total trade between India and ASEAN stands at US\$65 billion in 2015-16 (MEA). Former PM Dr. Manmohan Singh envisioned that the trade volume would reach US\$200 billion in the next decade. After the operationalization of India ASEAN Agreement on trade in goods in 2010, India has formally signed Free Trade Agreement for services and investments in 2014. The pact will allow India to leverage its competitive edge in the areas of finance, education, health, IT, telecommunication and transport. This will be especially helpful for balancing India's deficit with ASEAN countries in trade of goods.

\subsubsection{Improved Connectivity}

Of the many factors that contribute to building positive relations between India and the neighbouring countries, connectivity features at the very top. From the Indian perspective, connectivity is important for improving economic and trade relations with all the neighbouring nations, as well for improving links with the North Eastern region of India. The "Look East Policy" is incomplete without "physical connectivity". Myanmar serves as the land bridge between India and South Asian and South East Asian nations. India has been working on Mekong-Ganga cooperation which would connect ASEAN nations through Myanmar. The Mekong-India Economic Corridor (MIEC) will be a network of land and sea infrastructure which include India, Cambodia, Laos, Myanmar, Thailand and Vietnam. Mekong-India Economic Corridor will form an integral part of the India-ASEAN connectivity. This Corridor connecting Southeast Asia to South Asia on the eastern part of India would add greater momentum to the growing trade and investment linkages between ASEAN and India. Apart from MIEC, the Moreh/Tamu route of the India-Myanmar-Thailand Trilateral Highway is progressing well. Completion of this project is poised to create a new dynamic in India's multi-faceted relations with the region. India has backed the extension of this highway to Laos, Cambodia and Vietnam. A former Minister of India's Ministry of External Affairs has said that the Look East policy envisages the Northeast region not as the periphery of India, but as the centre of a thriving and integrated economic space linking two dynamic regions with a network of highways, railways pipelines, and transmission lines crisscrossing the region. PM Narendra Modi has announced a Line of Credit of US\$ 1 billion to promote projects that support physical and digital connectivity between India 
and ASEAN For really this to happen the policies and plans have to be proactively implemented and executed without any political and bureaucratic barriers.

\subsubsection{Security cooperation}

The main forum for ASEAN security dialogue is the ASEAN Regional Forum (ARF). India has been attending annual meetings of this forum since 1996 and has actively participated in its various activities. The ASEAN Defence Ministers' Meeting (ADMM) is the highest defence consultative and cooperative mechanism in ASEAN. The ADMM+ brings together Defence Ministers from the 10 ASEAN nations plus Australia, China, India, Japan, New Zealand, Republic of Korea, Russia, and the United States. The Defence Minister of India has attended the 3rd ADMM+ held from November 2015 in Kuala Lumpur. India has also participated in Expanded ASEAN Maritime Forum (EAMF) held in Manado, Indonesia on September 2015.

\subsubsection{ASEAN-India projects}

India has been cooperating with ASEAN by way of implementation of various projects in the fields of agriculture, science and technology, space, environment and climate change, human resource development, capacity building, new and renewable energy, tourism, and connectivity. Since 2011-12, while 13 projects have been completed, 17 projects are under implementation and 22 projects are in the planning stage, some of which are in the final stages of approval.

\subsection{India's Look East Policy and North-East India}

Programmatically, 'Look East' meant looking eastward for fostering newer ties with the immediate neighbours of South East Asia. Although the LEP in its present form got initiated during 1991, it was only in 2008 that North East India appeared in related policy formulation with the launch of NER Vision Document 2020. India's Northeastern states cannot be easily accessed from the mainland without Bangladesh's cooperation, so positive relations with India's South Asian neighbours will be crucial to enhancing its land connectivity with Southeast Asia. The Look East policy is thus a product of various compulsions, changed perceptions and expectations of India in the changed international environment. The interest for regional cooperation with ASEAN was based on the recognition of the strategic and economic importance of Southeast Asia to India's national interests. In this paper, we analyse the opportunities for North East region from The Look East policy of India (now Act East) and the challenges that might come up in the process. 
Before Independence, North East part of India was one of the most industrially advanced region. Tea plantation and tea manufacturing, plywood manufacturing, coal mining and oil refining were some of the prominent industry segments. The Digboi oil Refinery was set up in 1901 in Assam at Digboi by Assam oil company ltd. This was India's first oil refinery. The railways, roadways and inland water ways were fairly at advance stage to facilitate trade within the region as well as outside. But after independence and due to Partition, the region was turned into a landlocked territory with just a 22-km connecting link (through Siliguri) with the rest of India. Total area of North eastern states is of 262,179 square kilometers or about $8 \%$ of India's total area. Arunachal Pradesh is the largest state of Northeast. In terms of population Assam being the largest state also contribute highest to the Northeast's net state domestic product (NSDP). The North-East region has $5300 \mathrm{kms}$ of international borders with the nations like China, Myanmar, Bhutan, Nepal, and Bangladesh. Arunachal Pradesh, Manipur, Mizoram and Nagaland share a 1643 Kilometers border with Myanmar. Assam, Meghalaya, Tripura and Mizoram share 1880 Kilometers border with Bangladesh. Arunachal Pradesh, Assam, Sikkim share 460 Kilometers border with Bhutan and Sikkim and Arunachal Pradesh share 1325 Kilometers border with the Tibet autonomous region of the People Republic of China. The region is the home for 45 million culturally, ethnically, linguistically diversified and naturally bestowed people. The region is rich in natural resources, especially water and forests, and it could potentially be one of the wealthiest regions of India. With such geographical advantage the region could be easily the gateway to East Asian countries for all the economic activities and hence drive the growth engine of the country.

In reality, however, the overall growth of North East region over the past years have been abysmal sluggish. The region's economy is generally characterized by low per-capita income, low capital formation, inadequate infrastructure facilities, geographical isolation and communication bottleneck, inadequate exploitation of natural resources. Due to political division or unwillingness of political parties or the topographical difficulties hinder the undertaking of any development plan. Apart from political factor, unrest and insurgency is the one of the biggest reason for the low growth and development of the region. Despite the initiation of policy like North East Industrial and Investment Promotion Policy (2007) and granting 'special category' status to the region, most of the region still remains underdeveloped compared to other parts of India. Within the North-East region itself the growth pattern is widely imbalanced. Meghalaya and Sikkim have recorded highest growth rate in the region. But populous state like Assam, Manipur have seen below par growth. Per capita income is also below the 
national level in most of the region. The state wise economic performance of the NorthEast region has been given in Table 8 .

Table 8: Size of North-East States Economies (2014-15)

\begin{tabular}{|l|l|l|l|}
\hline State & Per capita (in ₹) & GSDP* (in crore) & NSDP*(crore) \\
\hline Arunachal Pradesh & 86,421 & 14,122 & 131,01 \\
\hline Assam & 42,349 & 156,895 & 138,387 \\
\hline Manipur & 43,348 & 15,030 & 133,83 \\
\hline Meghalaya & 39,503 & 145,61 & 128,02 \\
\hline Mizoram & 70,552 & 9,634 & 8,348 \\
\hline Nagaland & 58,998 & 141,15 & 121,24 \\
\hline Sikkim & 186,693 & 137,22 & 119,48 \\
\hline Tripura & 58,888 & 250,86 & 225,84 \\
\hline
\end{tabular}

Source: databank.nedfi.com

*NSPD - Net State Domestic Product; GSDP-Gross State Domestic Product

Mostly, the people of North East regions are engaged in primary economic activities, agriculture being predominant. Performance of industrial sector is not too encouraging due to absence of large scale industries in the region. Refinery, cement, fertilizer, paper and paper products are few notable industries present in the region. The lack of growth in industrial sector can be attributed to reasons like land acquisition problem, availability of power, transport and logistics, credit disbursal, skilled labour, marketing and taxation issues etc. Lack of sufficient infrastructure is main hurdle to growth and development of the whole North-East region. The look east policy of India can turn the fortune of the whole North east region if proactively implemented. One of the main objectives of the Look East Policy of India was to foster trade and economic relation with ASEAN countries and at the same time to overcome the imbalanced and low growth of North East states. Because of its geographical location, the North-East region can act as the land bridge between mainland of India and ASEAN. We have already seen that the FTA has been consistently boosting economic and trade ties with the ASEAN nations. The trade activities are expected to increase further with the completion of proposed Asian highway 1 and 2 which would connect Asian countries and pass through North East of India. This is expected to bring the must needed growth and development to North-East states. Now we will try to analyse how the Look East Policy of India can pave the way for developing North-East region of India and whether the region has the potential to become gateway of India to ASEAN. 


\subsection{Potential for the North-East states}

The potential for international trade though North East region is immense due to the fact that the region has international boundary of approximately 5300 kilometers with nations like China, Myanmar, Bangladesh, Bhutan, and Nepal. The whole region is bestowed with untapped natural resources. The North East region is well endowed with natural resources, like oil and gas, agro-horticultural resources, mineral deposits, immense hydroelectric potential and significant forest resources. With two major rivers, Brahmaputra and Barak, flowing through the region, the North-East accounts for about $34 \%$ of the country's water resources and possesses almost $40 \%$ of India's hydro power potential. Potential of North East region can be gauged from the following facts:

- The region has the potential to develop into a vibrant source of energy, oil, natural gas, coal, and limestone. The region is bestowed with natural gas reserves of 190 billion cubic metres, coal reserves of over 900 million tonnes and oil reserves of over 500 million tonnes. Large Mineral Resources including limestone reserves of around 5000 million tonnes and a forest cover which is 25 per cent of the country's forest area.( Source : FICCI)

- It is endowed with India's largest perennial water system - the river Brahmaputra and its tributaries and the Barak river. This can help generate hydro-power based energy, transforming the region into a source of clean energy powerhouse. The region has hydropower potential estimated at nearly 50,000 MW. (FICCI)

- The Brahmaputra valley provides fertile soil for cultivating horticultural products, plantation crops, vegetables, spices, rare herbs, and medicinal plants. Large variety of agricultural produce such as rice, maize, millets, sugarcane, jute, cotton, rubber, tea, mustard, grapes, guava, coconut, coffee, apples, pineapples, passion fruit, walnut, brinjal and a vast range of fruits and vegetables are produce in the region. Currently, three agricultural export processing zones are in operation.( Ginger Sikkim, Flowers(orchids) \& Cherry Pepper - Sikkim, Fresh and Processed Ginger Assam, Pineapple - Tripura)

- Potential for immense tourism opportunities exists due to the region's rich biodiversity, rare flora and fauna, natural scenic beauty, unique performing arts, and varied cuisine and handicrafts. The Tourism industry involves a vast network of business activities relating to hotels, restaurants, transport agency and several other related activities. The development of this industry would promote national integration and international understanding, generate employment and revenue in the region. 
- Geographical advantage exists due to proximity to countries in South and South-East Asia. North-East can emerge as a strategic base for foreign/ domestic investors to tap markets of South and Southeast Asia.

- Opening of a border custom station between Myanmar and North-East (Moreh in Manipur) along with the possibility of a second border trading point opening at Champhai, the region is seen as a corridor for flow of goods and services between India and Southeast Asia.

- North-East's internal waterway network connects the region with Bangladesh and Myanmar, giving access to the ports of Chittagong (Bangladesh), Calcutta and Haldia (West Bengal in India), and Sittwe (Myanmar).

- Industrial growth centres in NER has already been converted into tax-free zones for the next 10 years. Moreover, the government also offers incentives on transport, capital investment, and interest subsidy on working capital.(FICCI)

- A region with very high literacy rate (over $70 \%$ ), and large number of people fluent in English. A strong potential for growth of information technology enabled services.

The potential of the North East region can be realised with the rapid development in infrastructure specially connectivity. Connectivity is going to be one of the biggest boon for the region if properly developed. At present, the connectivity in the region is not up to the mark but it is making progress. The total length of NHs in the region is $8,480 \mathrm{~km}$ and the states have $5,711 \mathrm{~km}$ of state highways (SHs) and $15,154 \mathrm{~km}$ of major district roads. In most NE states, village and district roads are dominant. These roads are particularly important for facilitating intra state movement of people and freight. As far as air connectivity is concerned, the region has 11 airports in operation at present. The Lokpriya Gopinath Bordoloi International (LGBI) Airport in Guwahati, Assam, is the region's only international airport. In Sikkim, airport construction is underway in Pakyong. Inland water transport can be a viable, cost-effective alternative in the plains of the region, given the high cost of expanding other modes of transportation. Major river routes in the region are the Brahmaputra and the Barak rivers in Assam which have been declared as National Waterways 2 and 6 respectively. In all, the region has about 3,839 $\mathrm{km}$ of navigable river routes. The region has about 2,600 $\mathrm{km}$ of railway lines, but till today only two state capitals are connected by railway. Most of the railway lines are lying in the states of Assam and Tripura. Recently Arunachal Pradesh has been included in the railway network of India. Apart from the interior connectivity, the two Asian Highways will pass through the north east and will overlap with each other to effectively provide north east India connectivity with Bangladesh apart from Myanmar 
and other ASEAN countries. Such international connectivity will led to reallocation of trade and export hub to north east region. If business zones are relocated to north east region, there will be huge amount of cost savings in terms of logistics and transportation. According to a study conducted by PWC, that around 95\% of the total export to countries such as Bangladesh, Bhutan and Myanmar and around 99\% of the total trade with these countries is happening from regions other than the north east. Alongside, from the perspective of geographical locations, industry will save significant logistics costs, if they set up shop in the NE region. The setting up of trade and export shops in North East region will results in growth of other ancillary industries. In this process there will be large employment opportunities for localities of the region.

\subsection{Challenges in North East states}

Even if the region is bestowed with huge natural resources, the region is still lacking growth comparative to national level. Realisation of resources has been a daunting task due lack of accessibility. So if North East region is to be developed through the Look East Policy, then one of the primary requirement would be enhancing physical infrastructure.

\subsubsection{Physical infrastructure}

Physical infrastructure including road, rail and air connectivity is a serious problem in Northeast. Roads are real facilitator to transport connectivity and therefore need to be built and well maintained in the region. Currently most of the road are either not prepared or in dilapidated condition. The hilly terrain of the region makes it difficult and expensive to set up rail networks in the region. This is the main reason behind the absence of railway lines in the hilly states such as Arunachal Pradesh Manipur, Meghalaya and Mizoram. Many airports of the region are lying unused and many are not well maintained. Because of infrastructure issues, presently exports from North-East to ASEAN countries are routed through Kolkata and Haldia ports in West Bengal, nearly $1600 \mathrm{~km}$ from Northeast. The lack of logistical support and communication bottlenecks continues to hamper the region from fully realising its export potential in handicrafts, tea, spices etc. To facilitate free and fast movement of goods in the region as well as across the border, the connectivity issue has to address. Besides the connectivity issue, the infrastructure for banking facility, telecommunication, electricity supply etc. need to be adequately developed.

\subsubsection{Insurgency}

The problem of insurgency in the region has a long history. The persistence of insurgency can be attributed to political unwillingness, ignorance from Central 
Government, and most importantly lack of employment opportunities. The problem of insurgency has become the stumbling block in the course of development. It foundered every development strategy and hampered all the developmental works. Kidnapping, extortion, killing, strikes and curfews have become regular affairs. There are regular economic blockade hampering the movement of goods and services. Due to such kind instability the investors has been kept themselves away from the region. So Government need to take necessary steps at the earliest to solve the insurgency problem in the region. This would help in enhancing trade and investment in the region, thus creating employment opportunities.

\subsubsection{Land acquisition}

Land acquisition in the North Eastern region is difficult due to inaccurate or incomplete data of land ownership and resettlement issue of native people dependent on land and forests. The Central and state governments will have to come up with solution so that land acquisition process is simplified and speed up at the same time.

\subsection{Conclusion}

It has been three decades since the initiation of India's Look East Policy. Have we achieved what the policy was intended for? We cannot say outrightly that the Look East policy is a failure. In the last ten years, total trade between India and ASEAN has been growing at an average rate of 15 percent year on year. The total trade has increased from US $\$ 30.7$ billion in 2005-06 to US\$ 65 billion in 2015-16. The share of ASEAN in India's total trade has been average 10 percent. It would be immature to say the policy as a success because one of the main objectives of the policy to stabilise the North-East region is nowhere to be seen or if any, that is in a dismal pace. The Look East Policy was initiated with the objective of liberalisation of India's economy and improvement of the economic situation in North East India region. Look East policy was meant to look towards South East Asian nations through North-East region of India. However, in true sense the North East development agenda has been incorporated in the policy at a much later stage. It may be too early but the impact of the India's Look East Policy on the growth and development of North East region is nowhere to be seen. The potential of the region is not being fully utilized because of inadequate infrastructure and political ignorance. The problems cited above have persisted as far as North Eastern states are concerned. Initiatives for economic integration of the North-East region with ASEAN need to be preceded by an effective integration of the region with the mainstream of Indian polity and economics. This would require the removal of the North East 
population's general sentiment that they are alienated from the rest of India, the creation of adequate infrastructure and a conducive environment for free movement of economic and non-economic resources. The importance of India's current relationship with ASEAN and its future potential for mutually beneficial growth will require greater political, economic, and diplomatic engagement with ASEAN. India is emerging as a serious player in the Asian strategic landscape as smaller states in East Asia reach out to it for trade, diplomacy and, potentially, as a key regional balancer. The Look East Policy provided a tremendous encouragement to economic ties between India and the ASEAN member states. An aggregate analysis of Indo-ASEAN trade exhibits the importance of ASEAN in India's trade. It is observed that ASEAN's importance has been increasing since 1980. ASEAN as a region has displayed great dynamism. There is a large untapped potential for expansion of ASEAN-India merchandise trade from the present levels. The introduction of Look East Policy (now Act East) has been successful in developing political and economic ties with ASEAN and East Asian nations. With political will and improved connectivity, the trade volume is expected to increase further in the future. It remains to be seen if India can indeed live up to its full potential, as well as to the region's expectations.

\section{References}

Barua, Alokesh \& Das, S. K. (2008). Perspective on growth and development in the Northeast: The look east policy and beyond. Margin: The Journal of Applied Economic Research, 2(4), 327-350.

Chatterjee, Shibashis. (2007). Conceptions of space in India's look east policy: Order, cooperation or community. South Asian Survey, 14(2), 65-81.

Gogoi, Jayanta. (2014). Look east policy: Potentialities for north eastern region. Indian Journal of Applied Research, 4(5), 21-22.

Haokip, Thongkholal. (2011). India's look east policy. Third Concept - An International Journal of Ideas, 25(291), 7-11.

Haokip, Thongkholal. (2011). India's look east policy: Its evolution and approach. South Asian Survey, 18(2), 239-257. 
136 | FOCUS: Journal of International Business, Volume 4, Issue 1, January-June 2017

Haokip, Thongkholal. (2015). India's look east policy: Prospects and challenges for Northeast India. Studies in Indian Politics, 3(2), 1-14.

Jyoti. (2013). India's look east policy: In its second phase. Global Journal of Pharmaceutical Sciences and Education. 2(1), 1-14.

Ministry of External Affairs. (2016). Act East Policy. India. Retrieved from http://pib.nic.in/newsite/PrintRelease.aspx?relid=133837

Morarji, B. \& Sharma, Vishnubhatla N. V. L. N. G. (2015) Shifting trends in India and Southeast Asia relations. International Journal of Advanced Research in Management and Social Sciences, 4(2), 97-112.

Press Information Bureau, Government of India, Ministry of External Affairs. (2016). Act East Policy. Retrieved from http://pib.nic.in/newsite/PrintRelease.aspx?relid=133837

Saikia, Hemanta. (2010). Look east policy: Southeast Asian economic integration of India. Applied Economics Journal, 17 (2), 1-11.

Singh, Ranjan Kshetrimayum \& Singh, Ghanajit Ch. (2014). Look east policy: India's motive and opportunities and threats ahead. Asian Journal of Research in Business Economics and Management, 4(11), 165-171.

Sundaram, A. (2013). Look east policy. International Journal of Advancements in Research and Technology, 2(5), 169-185. 